\title{
DEMOCRACY IN THE EYES OF ISLAMISTS An Ideological Contest in Post-New Order Indonesia's Socio-Politics
}

\author{
Ahmad Fathan Aniq \\ IAIN Sunan Ampel, Surabaya - Indonesia
}

Book Review

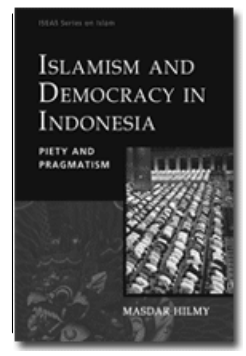
Book title : Islamism and Democracy in Indonesia; Piety and Pragmatism
Author : Masdar Hilmy
No. of Pages : $x i+320$
Year : 2010
Publisher : Institute of Southeast Asian Studies, Singapore

The discussion of Islam and democracy is obviously not new. This theme has already become the subject of discussion not only in Indonesia but also worldwide. Ongoing debates on whether or not Islam is compatible with democracy have even twisted misleadingly as if there is no correspondence between the two. This gave rise of stigmatization among the international community that Islam is not compatible with democracy.

Islam and democracy are indeed developed from different history. Islam is the religion where the teachings of which are believed to be revealed by God and it is definitely true, while democracy is the product of human ijtiha which is not free from various shortcomings. These fundamental differences ultimately gave birth to many unceasing debates between those who see the compatibility between Islam and democracy and those who do not. This never-ending polemic and its 
various socio-political dynamics have certainly attracted scholars' attention to review them.

Many studies have been conducted on the field. However, Masdar Hilmy's 'Islamism and Democracy in Indonesia, Piety and Pragmatism' is still a welcome contribution to the scholarship. Other studies are frequently trapped in viewing the relation between Islam and democracy as black and white phenomena. For modernist Muslims, democracy is compatible with Islamic values and thus it should be accepted. However, for revivalist Muslims, it is regarded as an infidels' product and is contradictory to God's sovereignty, therefore it must be rejected. Hilmy, through his publication, demonstrates the complexity of the phenomena and attempts to fill the gap by providing an analysis of Islamism and democracy in post-New Order Indonesia. For this reason, Hilmy chooses three Islamist organizations which have been trying to apply shari $>$ b as the basis of the nation. They are MMI (Majlis Mujahidin Indonesia/The Indonesian Council of Muslim Holy Wariors), HTI (Hizbut Tahrir Indonesia), and PKS (Partai Keadilan Sejahtera/Prosperous Justice Party). These three organizations were taken because they represent two ends of the spectrum of Islamist political ideas in contemporary Indonesian Islam. The first two organizations which are called 'utopian Islamists' represent the pole that employs extra-parliamentary struggle to reject democracy, while the later which is called 'meliorist Islamists' represents the pole that uses intra-parliamentary means to promote Islam through democracy.

The book, the content of which is an admirable wealth of detailed information, is divided into eight chapters, including the introduction and the conclusion. It is ended with Appendices, Bibliography and Index, and therefore once it is looked from the academic-writing point of view, by completely mentioning all these divisions, it can be considered as an academic book.

It is started with the introduction which becomes the first chapter. This chapter provides a clear background to the development of Islamism in post-New Order Indonesia, explaining efforts of the Islamists in replacing Pancasila, the philosophical foundation of the country, with Islam. The chapter also deals with the focus of the study, the main theoretical argument, the conceptual framework, the methodological note and the structure of the book.

The second chapter covers the relationship between Islam and democracy from a theoretical perspective. It is started with a 
discussion of the cultural essentialist approach to democracy which is represented by scholars such as Bernard Lewis, Samuel P. Huntington, and Francis Fukuyama who suggest that Islam is by nature incompatible with democracy. Indeed, Fukuyama asserts that Islam has stood as a major barrier to democratization (p.23). This approach is then countered by arguments of structural-instrumentalist approach. Unlike the culturalist approach, which relies heavily on religion as an autonomous variable, this approach puts its emphasis on social and political structures where religion and other factors interact with one another in a dialectical relationship. It is these elements, not Islam as a religion, that play a much greater role in determining whether a community will be more or less receptive to democracy. Finally, the chapter concludes with an overview of the internal debate within Muslim society, which reflects the multivocality of Islam.

In chapter three, Hilmy explains the discourse on Islam and democracy within Indonesian Islam. This chapter is concerned with three main issues: first, the conceptual definition of Indonesia's democracy; second, a brief historical account of the development of Indonesian concepts of, and experiences with, democracy; third, Indonesian Muslims' approaches to democracy which can be classified into 1) a liberal approach, 2) a meliorist approach, and 3) a utopian approach. Muslim scholars such as Munawir Sjadzali, Nurcholish Madjid, Abdurrahman Wahid, and Amien Rais are categorized as those who employed the first approach and they are who first attempted to lay the theological foundations for arguing the compatibility of Islam and democracy. According to them, Islam is in itself democratic. The last two approaches are further explored in the fourth chapter which is about Islamism in the Indonesian context since the fall of Soeharto.

The fourth chapter attempts to analyse the emergence and development of Islamism in post-New Order Indonesia. It provides a general overview of Indonesian Islamism and a brief description of the three Islamist organizations analysed in this study. There are two types of Islamism which can easily be identified in terms of their approaches to the ideology of Islamism and how it should be implemented at a practical level. The first type which is represented by PKS is engaged in a structural struggle through political system. The second type which is represented by MMI and HTI use social and cultural activism off the formal political stage to spread their ideology in establishing Islamist organizations. In spite of differences of articulation, these two 
manifestations of Islamism have a common denominator, their emphasis on the importance of Islam in the public sphere.

In chapter five, Hilmy analyses the discourses on democracy within the utopian variant of Islamist groups, that is HTI and MMI. These groups' arguments in using extra-parliamentary approach as their struggles are based on some points. First, the Islamic government they proposed is all-encompassing over all types of human-made system, including democracy. Second, to both groups, the parliamentary or political party system is a "political grave" for morally true Muslim activists. Third, overthrowing the existing government must be undertaken through gradual and evolutionary means by arming society and culture with Islamic values and practices (p.169). Although they reject democracy, they do not forbid their activists to vote candidates whose visions reflect the aspiration of Shariath. This shows, to some extents, a sense of ambivalence between vision and practice and hints their pragmatic attitude.

In chapter six, Hilmy explores what he calls the meliorist Islamists who accept democracy and it is well represented by PKS that mentions democracy as one of its values. What PKS means by democracy is the universal and basic values of democracy which is the capacity of mankind as khalitulah on earth to determine their own destiny. Furthermore, through the so-called 'Islamic politics', PKS has given new colour of Indonesian politics. For some PKS cadres, 'Islamic politics' differs significantly from 'political Islam' in that the latter makes power as the end of politics, while the former views politics as the field of dakwah. Thus, the politicization of Islam must be replaced by the Islamization of politics (p. 188). However, some observers sceptically view that PKS' acceptance of democracy is considered merely a strategy to win votes. Once they came to power, they might use democracy as a mechanism to impose undemocratic elements of religion onto society.

The seventh chapter analyses comparatively the two variants of Islamism in the light of power relation theory. Here are the comparisons between the two streams. On the one hand, they share with one another some views: first, Islam is a glorious religion and must be actualized at a practical level; second, the society should be transformed from its current manifestation to the one that encompasses the Islamic ummab; third, to some extents, they commit themselves to implement Shari axh through proposed national and local 
by-laws; fourth, they also agree to accomplish their goals in a peaceful manner.

In addition to above similarities, however, they are in conflict with each other. First, while the utopian Islamists tend to harness extraparliamentary approaches to politics, the meliorists subscribe to parliamentary approaches. Second, while the former takes an uncompromising attitude towards its "opponent", the latter tries to be realistic and accommodating to the existing power structures. For this, to some utopian Islamists, PKS no longer deserves to be called a committed or idealistic political party since it is too much concerned with power struggles in a purely pragmatic sense. However, Hilmy, like other observers, appreciates PKS' attempts to combine democracy and Islam. These efforts can serve as a bridge between two poles: antidemocracy groups such as MMI and HTI on the one hand and procivil society religious organizations which fully support democracy such as Muhammadiyah and NU on the other. If PKS successfully play its role, it is not impossible a new hybrid form of Islam-based democracy might emerge in Indonesia.

The last chapter sums up the study in terms of theoretical findings. The study shows that a new 'democracy' has not been produced yet as a result of the interaction of democracy and Islamism. The democracy of PKS seems to be similar to the existing "Theo-democracy" of Natsir or "Islamic democracy" of Mawdudi. Furthermore, what the meliorist Islamists wish to achieve is an "ideal democracy" without secularism, liberalism and individualism. Thus, their version of democracy might be characterized by the placement of religion at the centre of the public sphere, where every citizen is bounded by religiously inspired law.

Throughout all chapters, Masdar Hilmy raises many important and interesting issues on Islamism and democracy. It is interesting in the sense that Islamists' dialectics to democracy and their struggle to defend what they believe as a truth are sometimes coupled with pragmatism, such as shown in this book. Hilmy also smartly elaborates plenty and various data to build his arguments.

However, there are some simple mistakes in writing Arabic words and phrases. For example, the usage of na't and man $u \gg$ (head and modifier) in Arabic which should be similar in its definite and indefinite forms, such as "Khulafa $>$ l-Rastiduß”' (p. 37), "hłk kumat alIlafipah" (p. 44), "salaf al-słlih" (p. 218), which should be "al-Khulafa> 


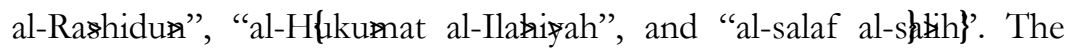
inconsistencies in writing Arabic words are also found, for instance "shahshiyah" (p. 118), "shakhshiyah" (p. 119), "al-salih" (p. 218), and "al-sirat" (p. 219). One cannot differentiate between $h \mathcal{d}(\tau)$ and kha $(\dot{\tau})$, as well as $\sin$ (u) $\boldsymbol{u}^{2} d \mathrm{~d}$ ( $\boldsymbol{\omega}$ in these words. It is perhaps because the book is not provided with the rules of Arabic transliteration. Another inconsistency is when Hilmy states that meliorist Islamists choose evolutionary methods of transformation, and the others (utopian Islamists) tend to prefer a revolutionary, radical transformation ( $p$. 244). Whereas in another page he states that utopian Islamists choose gradual and evolutionary means by arming society and culture with Islamic values and practices to topple the existing government (p.169).

Finally, this book should be read by those who want to understand Islamism and democracy in current Indonesia as well as by policy makers who want to make the right and wise decision dealing with the Islamist existence. As Hilmy suggests, "room in the public sphere for negotiation and participation must be opened as widely as possible for all elements of society, including Islamists, to define what constitutes the common good. By their participation, the Islamists will have to moderate their views and compromise with the rest of society" (p. 263). The existence of Islamists in democratic states is still acknowledged and regarded as long as they do not use coercive ways in disseminating their ideas. [] 